\title{
TEORETIČNO-METODOLOŠKI VIDIKI SISTEMSKEGA GEOGRAFSKEGA RAZISKOVANJA POKRAJINSKE DEGRADACIJE
}

\author{
Dušan Plut*
}

Izvleček

UDK 91:50:001.8

Za sistemsko zasnovano raziskovanje degradacije geografskega okolja so se uveljavili naslednji metodološki pristopi: fizičnogeografski, ekosistemski, socialnoekološki, pokrajinskoekološki in funkcijsko-regionalnogeografski.

Ključne besede: splošna sistemska teorija, pokrajinski sistem, pokrajinska degradacija

\section{THEORETICAL'METHODOLOGICAL ASPECTS OF SYSTEMIC GEOGRAPHICAL INVESTIGATION INTO LANDSCAPE DEGRADATION}

Abstract

UDC 91: $50: 001.8$

The following methodological approaches have been developed in the systemically planned investigation into the degradation of geographical environment: the physico-geographical, the ecosystemic, the socio-ecological, the landscape-ecological, and the functional regional-geographical ones.

Key words: General systemic theory, Landscape system, Landscape degradation

\section{I}

Proučevanje večplastnega, torej tudi prostorsko zasnovanega odnosa človek-okolje, je ena izmed predmetnih osnov geografskega raziskovanja. $\mathrm{Z}$ okoljem geografija pojmuje skupno vsoto življenjskih pogojev, ki obdajajo človeka na vsaki točki zemeljskega površja. Za človeka pred neoliotsko kmetijsko in pred novoveško industrijsko revolucijo so bili pogoji skoraj v celoti zgolj naravni in so vključevali naravne pokrajinotvorne dejavnike, kot so podnebje, relief, vode, prst in vegetacija. $\mathrm{Z}$ razvojem civilizacije se je človek vse bolj obdajal $\mathrm{z}$ antropogeno nastalimi elementi, ki so postali integralni del okolja (Haggett, 1972, str. 10). Preoblikovanje okolja je stalen, a časovno in prostorsko različno intenziven proces (Radinja, 1972). Vezi med družbo in okoljem se niso zrahljale, temveč so postale celo tesnejše, raznovrstnejše in bolj vsestranske, spremenila se je le njuna vloga $v$ medsebojnem součinkovanju. Zato je

* Dr. izr. prof., Oddelek za geografijo, Filozofska fakulteta Univerze v Ljubljani, Aškerčeva 2, 61000 Ljubljana, Slovenija 
potrebno upoštevati celovitost človekovega okolja; sestavljenega iz medsebojno prepletenega pokrajinskega mozaika naravnih in družbenih sestavin. V mestnem okolju že prevladujejo antropogene sestavine, človek pa je vse bolj aktiven preoblikovalec geografskega okolja, s snovno-energetskimi vnosi je postal po moči pokrajinskega preoblikovanja primerljiv z naravnimi silami (potresi, vulkani). Tako s povečano gostoto prebivalstva in razvojem tehnologije narašča njegova sposobnost neposrednega spreminjanja kvalitete okolja, le-to pa po določenem reakcijskem času povratno vpliva na nosilca preoblikovanja (Haggett, 1972, str. 11). (Diagram 1). Mesto je dinamičen sistem s kaotičnimi, nepredvidljivimi stanji (Klemenčič, 1992, str. 154) Prav gotovo je nastajajoča teorija kaosa izziv tudi raziskovanju pokrajinske degradacije kompleksnih mestnih sistemov, kjer linearne teorije pogosto odpovedo.

Ob naravnih obremenitvah okolja, ki jih predstavljajo ekstremni abiotski in biotski dejavniki (ob nenadnem izbruhu vulkanov, množičnem pojavu kobilic), narašča vloga antropogenih obremenitev okolja. Z njimi označujemo vplive vseh dejavnikov, ki so posledica človekove dejavnosti in so fizikalne ali kemične narave (Odzuck, 1982). Prekomerna onesnaženost ali degradacija okolja kaže na tisto stopnjo preobrazbe okolja, ki je nevarna za človekov obstoj ali nadaljni razvoj, ko je v okolju naravni potencial prekoračen do te stopnje, da narava s svojimi samočistilnimi sposobnostimi ne more več nevtralizirati in presnavljati emisij $\mathrm{v}$ vseh treh agregatnih stanjih (Radinja, 1972; Špes, 1994, str. 9) Onesnaževanje okolja ima svoj vir (fizični in kemični povzročitelji, mikororganizmi), učinek in posledice (Lah, 1995, str. 222). Destruktivno spreminjanje okolja se kaže tudi v prekomernem izkoriščanju naravnih virov, ki temelji na zmotnem prepričanju, da so naravni viri praktično neizčrpni.

Poudarjena aktivna vloga človeka pri preoblikovanju okolja raziskujemo s pomočjo različnih modelov kot preslikave trenutno vodilnih znanstvenih paradigm. Znanstvene paradigme odsevajo filozofsko raznolikost in vrednostno večplastnosti določenega duhovno-materialnega trenutka človeške civilizacije in zato ponujajo različno videnje in razumevanje ustroja in organiziranosti sveta (Drozg, 1991). Zgodnji, geografsko deterministični modeli odnosa človek $=$ okolje so pretirano, celo enostransko poudarjali vlogo narave (in okolja) za delovanje človeške civilizacije. Posibilistični modeli so v ospredje postavljali možnosti, ki jih človeku nudi narava (naravni viri). Modeli, ki so zasnovani na spoznanjih nujnosti sožitja človeka z naravo, izhajajo iz (bio) ekologije, prek zaznave okolja pa iz psihologije oziroma sociologije (Plut, 1991). Vse kompleksnosti realnosti in večplastnosti odnosa človek-okolje seveda ni in najbrž nikoli ne bo možno popolnoma celovito prikazati, saj je še tako dodelan model le bolj ali manj posrečena, poenostavljena podoba realnosti. Geografski modeli in metodološki prijemi sodobnega proučevanja odnosa človek-okolje poskušajo $\mathrm{z}$ različnih zornih kotov osvetliti pokrajinsko rezultanto tega večdimenzionalnega odnosa in se tako približati realnemu svetu, pokrajini. Pospešeno izčrpavanje omejenih naravnih virov in pokrajinsko-degradacijski procesi lokalnih, regionalnih, kontinentalnih in celo 


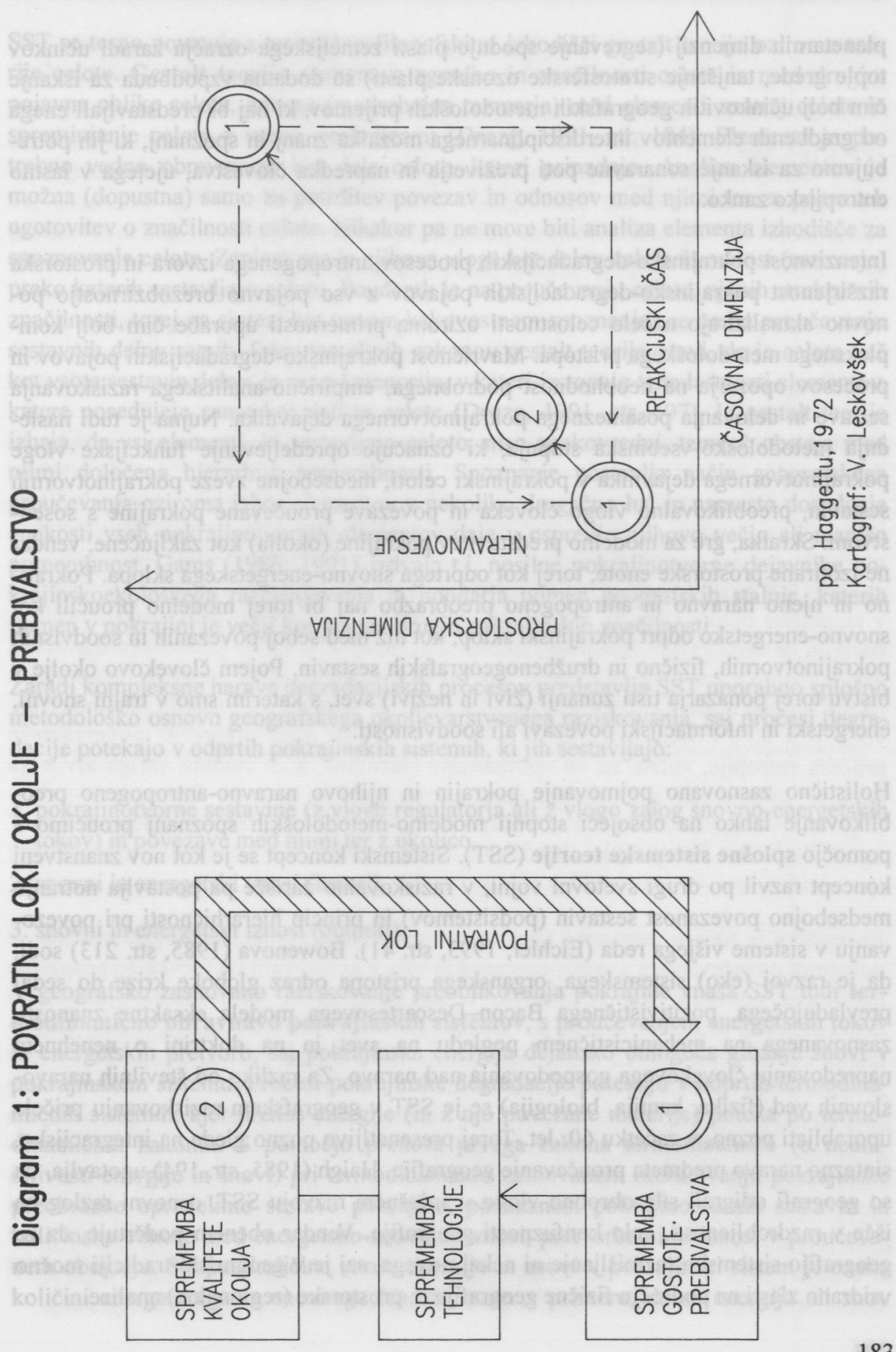


planetarnih dimenzij (segrevanje spodnje plasti zemeljskega ozračja zaradi učinkov tople grede, tanjšanje stratosferske ozonske plasti) so dodatna vzpodbuda za iskanje čim bolj učinkovitih geografskih metodoloških prijemov, ki naj bi predstavljali enega od gradbenih elementov interdisciplinarnega mozaika znanj in spoznanj, ki jih potrebujemo za iskanje sonaravne poti preživetja in napredka človeštva, ujetega $v$ lastno entropijsko zanko.

Intenzivnost pokrajinsko-degradacijskih procesov antropogenega izvora in prostorska razširjenost pokrajinsko-degradacijskih pojavov z vso pojavno brezobzirnostjo ponovno aktualizirajo načelo celostnosti oziroma primernosti uporabe čim bolj kompleksnega metodološkega pristopa. Mavričnost pokrajinsko-degradacijskih pojavov in procesov opozarja na neobhodnost podrobnega, empirično-analitskega raziskovanja sestave in delovanja posameznega pokrajinotvornega dejavnika. Nujna je tudi naslednja metodološko-vsebinska stopnja, ki označuje opredeljevanje funkcijske vloge pokrajinotvornega dejavnika $v$ pokrajinski celoti, medsebojne zveze pokrajinotvornih sestavin, preoblikovalno vlogo človeka in povezave proučevane pokrajine s sosedstvom. Skratka, gre za modelno predstavitev pokrajine (okolja) kot zaključene, vendar ne izolirane prostorske enote, torej kot odprtega snovno-energetskega sklopa. Pokrajino in njeno naravno in antropogeno preobrazbo naj bi torej modelno proučili kot snovno-energetsko odprt pokrajinski sklop, kot niz med seboj povezanih in soodvisnih pokrajinotvornih, fizično in družbenogeografskih sestavin. Pojem človekovo okolje v bistvu torej ponazarja tisti zunanji (živi in neživi) svet, s katerim smo v trajni snovni, energetski in informacijski povezavi ali soodvisnosti.

Holistično zasnovano pojmovanje pokrajin in njihovo naravno-antropogeno preoblikovanje lahko na obsoječi stopnji modelno-metodoloških spoznanj proučimo s pomočjo splošne sistemske teorije (SST). Sistemski koncept se je kot nov znanstveni koncept razvil po drugi svetovni vojni, $v$ raziskovalno žarišče pa postavlja notranjo medsebojno povezanost sestavin (podsistemov) in princip hierarhičnosti pri povezovanju v sisteme višjega reda (Eichler, 1993, str. 41). Bowenova (1985, str. 213) sodi, da je razvoj (eko) sistemskega, organskega pristopa odraz globoke krize do sedaj prevladujočega, pozitivističnega Bacon-Descartesovega modela eksaktne znanosti, zasnovanega na mehanicističnem pogledu na svet in na doktrini o nenehnem napredovanju človekovega gospodovanja nad naravo. Za razliko od številnih naravoslovnih ved (fizika, kemija, biologija) se je SST v geografskem raziskovanju pričela uporabljati pozno, v začetku 60 . let. Torej presenetljivo pozno glede na integracijsko, sintezno naravo predmeta proučevanje geografije. Haigh (1985, str. 194) ugotavlja, da so geografi odigrali sila obrobno vlogo v splošnem razvoju SST, osnovni razlog pa išče $v$ razdrobljenosti, celo konfuznosti geografije. Vendar obenem podčrtuje, da za geografijo sistemsko razmišljanje ni nekaj novega, saj je $v$ geografski tradiciji močno vsidrano zlasti na področju fizične geografije in prostorske (regionalne) analize. 
SST se tesno povetuje s teoretično-filozofskimi izhodišči gestalt teorije oziroma teorije celote. Gestalt teorija obravnava zgradbo in značilnosti celote in med drugim pojavne oblike celote, odnose (medsebojna razmerja) med elementi znotraj celote in spreminjanje celote z vsemi posledicami (Drozg, 1991, str. 104). Elemente je potrebno vedno obravnavati kot dele celote, kateri pripadajo. Analiza elementov je možna (dopustna) samo za potrditev povezav in odnosov med njimi ter za popravek ugotovitev o značilnosti celote. Nikakor pa ne more biti analiza elementa izhodišče za spoznavanje celote. Zanima nas le njihova vloga kot delov celote in odnosi (razmerja) preko katerih sestavljajo celoto. Poudarek je na proučevanju celote, njenih strukturnih značilnosti, torej na sintezi kot novem kakovostnem spoznanju, ne pa na proučevanju sestavnih delov samih. Eden temeljnih zakonov gestalt teorije pravi, da je celota več kot vsota sestavin delov, je nova kategorija, $v$ kateri izstopajo tiste lastnosti elementov, katere posedujejo samo kot deli te celote (Drozg, 1991, str. 107). Iz gestalt teorije izhaja, da vsi elementi, ki sestavljajo celoto, niso enakovredni, temveč obstaja med njimi določena hierarhija pomembnosti. Spoznanje postavlja način geografskega proučevanja oziroma izbor elementov $\mathrm{v}$ nekoliko drugačno luč in namesto dosedanje enakosti vseh pokrajinotvornih elementov daje $\mathrm{v}$ ospredje njihovo večjo ali manjšo pomembnost. Gams $(1986 ; 1991)$ izdvaja t.i. nosilne pokrajinotvorne dejavnike pokrajinskoekološkega razčlenjevanja in poudarja pomen geografskih stalnic, katerih pomen v pokrajini je večji kot pomen drugih pokrajinskih značilnosti.

Zaradi kompleksne narave degradacijskih procesov predstavlja SST uporabno splošno metodološko osnovo geografskega okoljevarstvenega raziskovanja, saj procesi degradacije potekajo $\mathrm{v}$ odprtih pokrajinskih sistemih, ki jih sestavljajo:

1. pokrajinotvorne sestavine ( $\mathrm{z}$ vlogo regulatorja ali $\mathrm{z}$ vlogo zalog snovno-energetskih tokov) in povezave med njimi ter z okolico,

2. snovni in energetski vnosi (inputi),

3. snovni in energetski iznosi (outputi).

V geografsko zasnovano raziskovanje preoblikovanja pokrajine vnaša SST tudi termodinamično obravnavo pokrajinskih sistemov, $s$ proučevanjem energetskih tokov in energetskih pretvorb, saj pokrajinska energija dejansko omogoča gibanje snovi v pokrajinskem sistemu. Procesi pokrajinske degradacije potekajo $v$ odprtih termodinamičnih sistemih, kjer prenos energije (in z njo povezane materije) poteka po termodinamičnih zakonih. $\mathrm{S}$ pomočjo prenosa prvega zakona termodinamike (o neuničljivosti energije in snovi) pri termodinamično zasnovanem raziskovanju pokrajinske preobrazbe opredelimo sestavo pokrajine, povezanost pokrajinotvornih sestavin in količinske odnose med energetsko-snovnimi vnosi, pretvorbami in iznosi v proučevanem območju. Skupna količina vnosa energije in snovi v pokrajinski sistem je enaka količini energetskega in snovnega iznosa, razen $v$ primeru, da se energija ali snov 
shranita v pokrajinskem sistemu, kar povzroči prostorske spremembe $\mathrm{v}$ snovno-energetski razporeditvi pokrajinotvornih sestavin in količinske spremembe $v$ pokrajinskem ravnovesju.

$s Z P=I P-O P$

$$
\begin{aligned}
& \text { sZP - sprememba zalog pokrajinskega sistema } \\
& \text { IP - vnos v pokrajinski sistem } \\
& \text { OP - iznos iz pokrajinskega sistema }
\end{aligned}
$$

V naravnih pokrajinskih sistemih so prisotni zgolj tokovi sončne energije kot proste energije iz okolice, $v$ antropogenih sistemih pa tudi drugi energetski viri (npr. zaloge fosilnih goriv). Če bi veljal le prvi zakon termodinamike, bi se energija $v$ pokrajinskem sistemu lahko vedno znova koristila in pretvarjala iz ene oblike $\mathbf{v}$ drugo. Preoblikovanje proste energije poteka pod vplivom drugega zakona termodinamike, $\mathrm{ki}$ določa način in smer preoblikovanja proste energije (Strnad, 1987). Pri vsakokratnem preoblikovanju energije in snovi iz ene oblike $v$ drugo se zmanjša skupna količina izkoristljive energije, ki je več ni mogoče pretvoriti $v$ delo. Ob vsaki energetski pretvorbi prihaja torej do entropije kot fizikalnega merila nepovračljivosti energije, oziroma kot kvantitativne mere degradacije energije, njene pretvorbe iz koncentirane v razpršeno obliko (Rifkin, 1986; Capra, 1986). Ob sežiganju premoga ali nafte se energija ne izgubi (prvi zakon termodinamike), temveč se delno pretvori (drugi zakon termodinamike oziroma entropijski zakon) $\mathrm{v}$ uporabno obliko za delo, delno $\mathrm{v}$ odpadno toploto (jalova energija) in delno v pline, ki se širijo v hladnejšo okolico (zrak, voda, prst itd.). Prisotnost življenja v biosferi sicer ne more preprečiti univerzalnega procesa entropije, vpliva pa na upočasnenje (skromna, a za celotno verigo življenja izjemno pomembna akumulacija sončne energije) in na sam vzorec entropijske degradacije (Georgescu-Roegen, 1986; Kirn 1985). Entropijski zakon "brezobzirno" ugotavlja, da na Zemlji ni končen le prostor, surovine, rodovitna prst in samočistilne sposobnosti, temveč tudi količina proste energije.

Energetske in snovne pretvorbe torej vedno spremlja degradacija energije in snovi, z dodatnim povečevanjem snovno-energetskih tokov in pretvorb pa človek še pospešuje naraščanje entropije, kar je osnovni vzrok nastanka in povečevanja pokrajinsko degradacijskih procesov, le-ti pa povzročajo onesnaženost oziroma pokrajinsko degradacijo okolja (Plut, 1991). S pomočjo prostorsko-časovne analize energetskih tokov pokrajinskega sistema lahko dodatno osvetlimo vzročno-posledične in ostale odnose preobrazbe pokrajin. V antropogenih, za razliko od naravnih sistemov, prevladujejo pozitivni povratni loki, ki dodatno pospešujejo naravne, spontane entropijsko-degradacijske procese. Pokrajinska degradacija označuje stanje, v katerem destruktivni, pozitivni povratni loki presegajo samoregulacijske zmogljivosti pokrajine. Različni naravni in antopogenizirani sistemi imajo glede na notranjo strukturo zelo različne samočistilne sposobnosti, pa tudi različno dolg reakcijski čas na spremembe snovno-energetskih vnosov (Chorley-Kennedy, 1971). 
Z vidika pokrajinske degradacije je potrebno podčrtati, da imajo po sestavi bolj raznoliki sistemi praviloma večje samočistilne sposobnosti, krajši reakcijski čas odziva na spremembe in se hitreje prilagajajo nihanjem snovno-energetskih vnosov. Raznoliki naravni sistemi imajo tudi številne mehanizme za vzdrževanje ravnovesja v snovno-energetskih tokovih. Dolžina reakcijskega časa je odvisna torej od pokrajinske sestave, predvsem od njenih t.i. skladiščnih zmogljivosti za snovi in energijo. Pri proučevanju degradacijskih procesov je potrebno ob ooceni zmogljivosti mehanizmov pokrajinskega ravnovesja čim bolj natančno oceniti tako reakcijski čas pokrajinskega sistema kot celote in še posebej reakcijski čas najbolj ogroženih oziroma obremenjenih pokrajinotvornih sestavin ob izjemno visokem, nerednem in kratkotrajnem porastu emisijskega vnosa (npr. izliv odpadnih voda $v$ poletnem času minimalnih vodnih pretokov, temperaturna inverzija v zimskem času kurjenja s fosilnimi gorivi).

$\mathrm{Z}$ vidika SST je pri proučevanju pokrajinske degradacije potrbno proučiti naslednje vsebine:

a. pokrajinotvorne sestavine in njihova medsebojna razmerja,

b. dinamiko pokrajinskega sistema (snovne in energetske tokove),

c. odziv pokrajinotvornih sestavin in pokrajinskega sistema kot celote na antropogeno zasnovane spremembe $\mathrm{v}$ snovno-energetskih tokovih,

d. možnosti in načine nadzorovanja ter zmanjšanja negativnih vplivov zaradi posegov človeka v dinamično pokrajinsko ravnovesje.

\section{II}

V okviru sistemsko zasnovanih splošnih metodološko-teoretičnih pristopov so se za proučevanje pokrajinske degradacije izoblikovali naslednji osnovni metodološki pristopi:

1. fizičnogeografski,

2. ekosistemski,

3. socialnoekološki,

4. pokrajinskoekološki,

5. funkcijski regionalnogeografski.

1. Tradicionalni fizičnogeografski oziroma naravnogeografski metodološki pristop izhaja iz delitve pokrajine $v$ fizičnogeografske in družbenogeografske sestavine, $v$ ospredje pa postavlja proučevanje pokrajinskih posledic antropogenih obremenitev v posameznih naravnogeografskih sestavinah: v ozračju, vodi, reliefu, prsti in vegetaciji (Strahler et al., 1974). Poudarjeno je raziskovanje posledic človekovega posega v pokrajinotvoerne sestavine, zlasti v ozračje in v vodne vire. Pogosto se uporablja empirično analitsko raziskovanje s pomočjo modela sfer (litosfera, hidro- 
sfera, atmosfera itd.), torej vertikalno zasnovan model, ki ločeno proučuje sestavo in dinamiko posameznih sfer (Eichler, 1993, str. 41). Fizičnogeografske raziskave onesnaženosti okolja poudarjajo pomen meritev obremenitve okolja in različnega odziva naravnih pokrajinotvornih sestavin na obremenjevanja okolja. Energetsko-entropijski (termodinamični) pristop je v klasično, na snovnih tokovih zasnovano fizičnogeografsko proučevanje, vnesel obravnavo pokrajinske degradacije s pomočjo energetskih tokov in bilanc, saj so vsi pokrajinski sistemi na Zemlji tudi energetski sistemi (Strahler et al., 1974). V urbano-industrijskih območjih je energetska gostota (količina porabljene energije na enoto površine) tudi več kot 1000 -krat večja kot v gozdnem ekosistemu (Odum, 1989, str. 9). Obenem je proučevanje energetskih tokov, kroženja kemičnih elementov in pokrajinskih vplivov človekove dejavnosti omililo analitsko-empirično zasnovano proučevanja fizičnogeografskih sfer (Diagram 2).

2. Ekosistemski metodološki pristop izhaja iz opredelitve ekološkega (eko) sistema kot odprtega biološkega sistema, sestavljenega iz biotopa in biocenoze. Strukturo ekosistema sestavljajo fizikalno-kemični dejavniki z značilno prostorsko, kakovostno in količinsko različnostjo in biološki elementi s svojo taksonomsko, fiziološko in ekološko raznolikostjo (Tarman, 1992, str. 263). Osnovne funkcije ekosistema so $v$ akcijah in reakcijah organizmov in populacij, $v$ kroženju snovi in pretoku energije (zelene rastline-rastlinojedci-mesojedci-razkrojevalci). Sončna energija je stalen in obnovljiv energetski vir, ki direktno oskrbuje naravne ekosisteme in omogoča kroženje vode, zraka in prehrambenih snovi (Odum, 1989, str. 39). Kemične elemente in sestavine lahko za razliko od enosmerne rabe sončne in ostale energije uporabimo neštetokrat in jih raziskujemo v biogeokemičnih krogih (npr. ogljik, kisik, voda). Strukturo in funkcijo ekosistema raziskujemo s pomočjo ekosistemske analize (s pomočjo uporabe poenostavljenih matematično-ekoloških modelov), $s$ katero spoznavamo sestavo vrst, zveze med organskimi vrstami (združbami), produkcijske odnose (pretoke snovi in energije, prehranjevalne verige in splete, trofične ravni) in poti v zrelost ekosistemov ali ekološke sukcesije (Tarman, 1992, str. 263) (Diagram 3).

Zaradi vse bolj aktivne vloge človeka v ekosistemih sodobne definicije poudarjajo trojno sestavo ekosistemov: živa bitja, nežive naravne sestavine in tehnični (antropogeni) elementi. To so podsistemi, ki so med seboj in $\mathrm{z}$ okolico energetsko, snovno in informacijsko povezani (Eichler, 1993) (Diagram 4). Tako pojmovanje ekosistemov se približuje sistemsko zasnovanemu, sodobnemu geografskemu pojmovanju odprtega pokrajinskega sistema, sestavljenega iz naravnih (živih in neživih sestavin) in antropogenih sestavin $\mathrm{v}$ medsebojni večdimenzionalni, mrežni soodvisnosi in součinkovanju. Vpliv človeka na ekosisteme je dvojen: z biotskimi dejavniki (uvajanje neavtohtonih vrst, odstranjevanje avtohtonih vrst, uvajanje obolelih organizmov) in z abiotskimi dejavniki (onesnaževanje, izčrpavanje naravnih virov). Tako spremembe z biotskimi kot $\mathrm{z}$ abiotskimi dejavniki vodijo $\mathrm{k}$ poenostavitvam ekosistemov, kar povzroča ekosistemsko neravnovesje in celo propad ekosistema (Chiras, 1988, str. 94). 


\section{Diagram 2: MODELNA PREDSTAVITEV FIZIČNOGEOGRAFSKE SESTAVE IN DINAMIKE POKRAJINE}

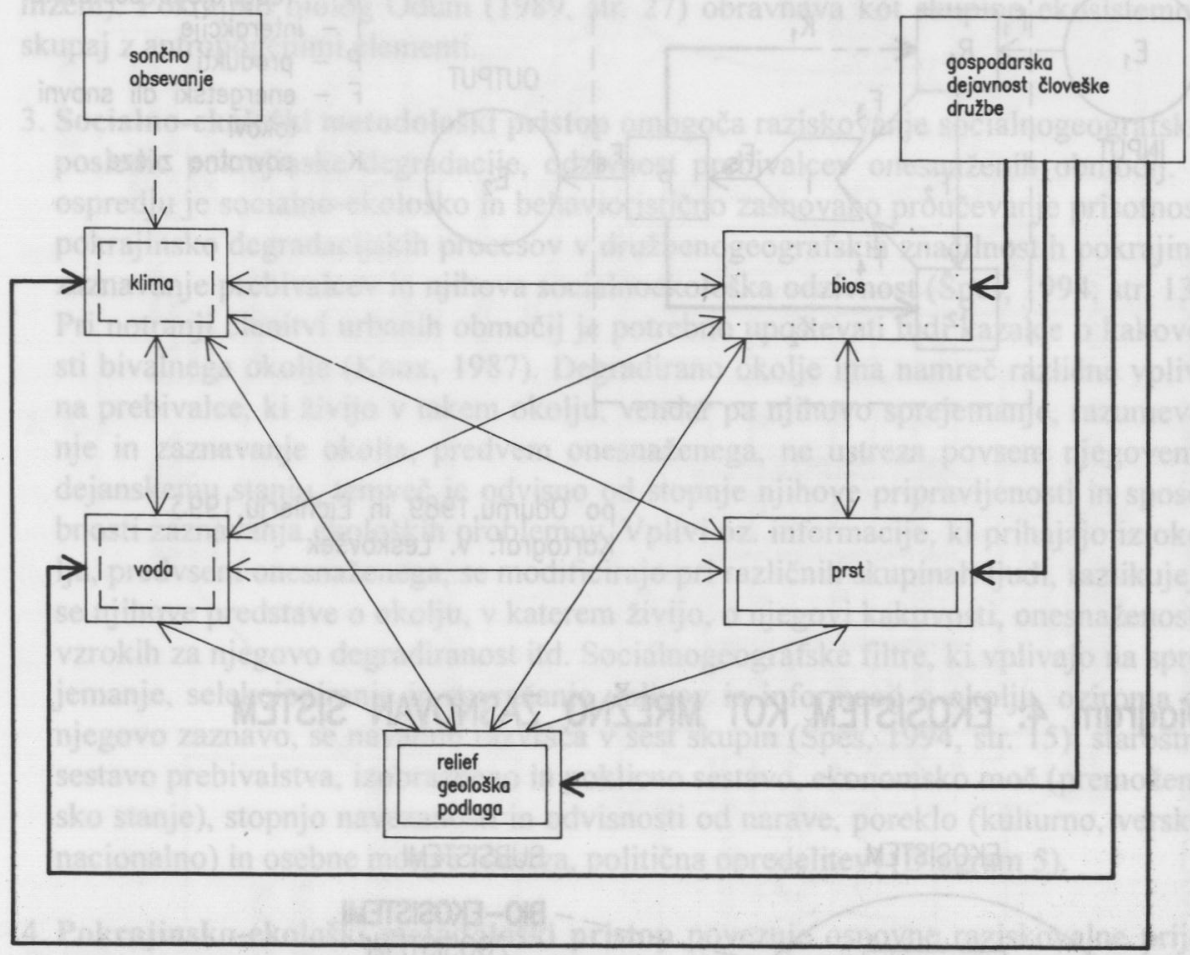

FIZICNOGEOGRAFSKE SESTAVINE

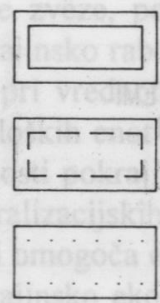

stabilne

$$
\text { variabilne }
$$

labilne

Leser (1976) po Bartschu, 1971

Kartograf: V. Leskovšek 


\section{Diagram 3: SISTEMSKI DIAGRAM OSNOVNIH ELEMENTOV EKOSISTEMA}

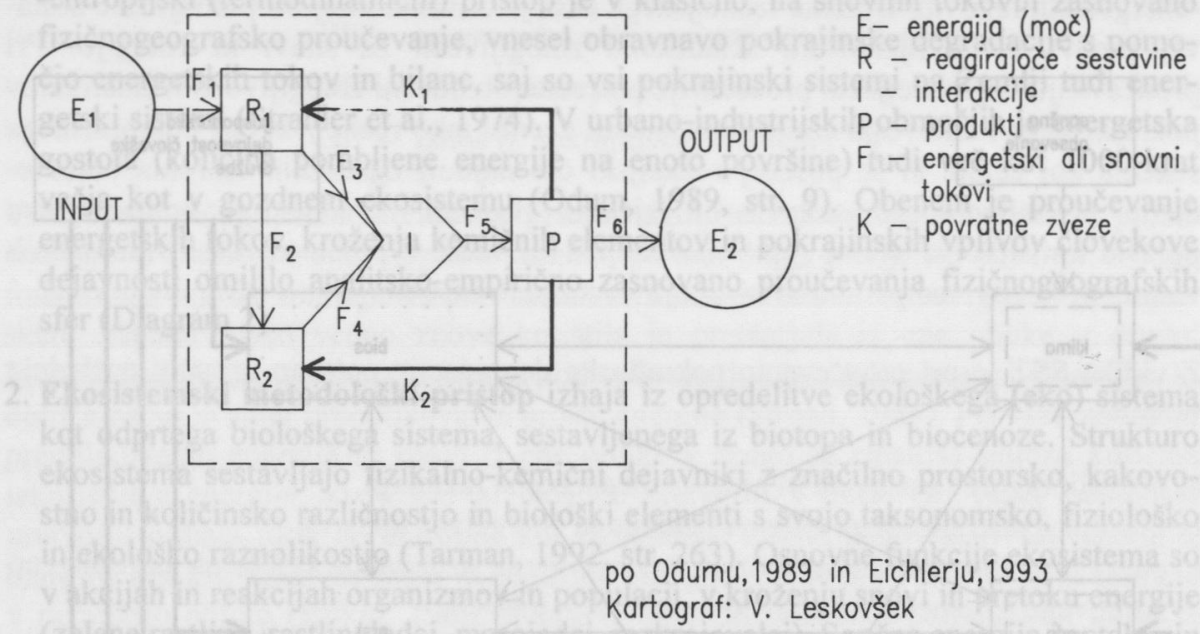

\section{Diagram 4: EKOSISTEM KOT MREŽNO ZASNOVAN SISTEM}

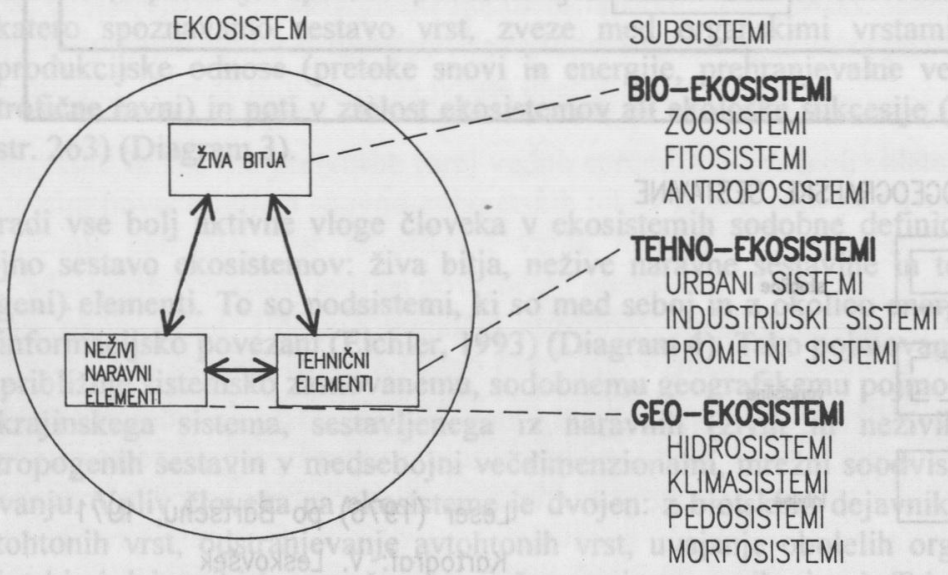

Eichler, 1993

Kartograf: V. Leskovšek 
Pokrajinsko, torej geografsko zasnovano proučevanje (pokrajinskih) ekosistemov, postavlja $\vee$ ospredje pokrajinsko preoblikovalno vlogo človeka in ekosistemske spremembe vrednoti $\mathrm{z}$ vidika spremenjenih bivalnih in ostalih pogojev za življenje človeka. S tega vidika je ilustrativna Odumova (1989) primerjava geografskih in ekoloških (bioloških) organizacijskih hierarhičnih nivojev, kjer je pokrajina uvrščena v ekološke hierarhične stopnje (biosfera-biom-pokrajina-ekosistem-populacija-organizem). Pokrajino biolog Odum (1989, str. 27) obravnava kot skupino ekosistemov, skupaj $\mathrm{z}$ antropogenimi elementi.

3. Socialno-ekološki metodološki pristop omogoča raziskovanje socialnogeografskih posledic pokrajinske degradacije, odzivnost prebivalcev onesnaženih območij. V ospredju je socialno-ekološko in behavioristično zasnovano proučevanje prisotnosti pokrajinsko degradacijskih procesov $\mathrm{v}$ družbenogeografskih značilnostih pokrajine, zaznavanje prebivalcev in njihova socialnoekološka odzivnost (Špes, 1994, str. 13). Pri notranji členitvi urbanih območij je potrebno upoštevati tudi kazalce o kakovosti bivalnega okolja (Knox, 1987). Degradirano okolje ima namreč različne vplive na prebivalce, ki živijo $v$ takem okolju, vendar pa njihovo sprejemanje, razumevanje in zaznavanje okolja, predvem onesnaženega, ne ustreza povsem njegovemu dejanskemu stanju, temveč je odvisno od stopnje njihove pripravljenosti in sposobnosti zaznavanja ekoloških problemov. Vplivi oz. informacije, ki prihajajo iz okolja, predvsem onesnaženega, se modificirajo pri različnih skupinah ljudi, razlikujejo se njihove predstave o okolju, v katerem živijo, o njegovi kakovosti, onesnaženosti, vzrokih za njegovo degradiranost itd. Socialnogeografske filtre, ki vplivajo na sprejemanje, selekcioniranje in zavračanje vplivov in informacij o okolju, oziroma na njegovo zaznavo, se navadno razvršča v šest skupin (Špes, 1994, str. 15): starostno sestavo prebivalstva, izobrazbeno in poklicno sestavo, ekonomsko moč (premoženjsko stanje), stopnjo navezanosti in odvisnosti od narave, poreklo (kulturno, versko, nacionalno) in osebne motive (čustva, politična opredelitev) (Diagram 5).

4. Pokrajinsko-ekološki metodološki pristop povezuje osnovne raziskovalne prijeme fizične geografije in (bio)ekologije. $\mathrm{V}$ ospredju ni le raziskava posameznih pokrajinskoekoloških elementov, temveč njihovo kompleksno vrednotenje ter medsebojne zveze, pokrajinskoekološka struktura z vidika pogojev za življenje ali za pokrajinsko rabo (Leser, 1976; Gams, 1986). Vloga pokrajinskoekoloških dejavnikov pri vrednotenju naravnega potenciala in ranljivosti posameznih pokrajinsko-ekoloških enot je zelo različna. Pokrajinskoekološka členitev in analiza ustreznih lastnosti pokrajinotvornih sestavin posameznih pokrajinskoekoloških enot $\mathrm{z}$ vidika nevtralizacijskih in regeneracijskih zmogljivosti ter proucitev polucijske obremenljivosti omogoča opredelitev stopnje ranljivosti okolja oziroma ranljivosti posamezne pokrajinsko ekološke enote (Špes-Plut-Natek K.-Natek M., 1994). Ocena pokrajinske (ekološke) ranljivosti izhaja iz ocen samočistilnih sposobnosti in iz ocen o doseženi stopnji emisijske in ostale obremenitve pokrajinskih sestavin in pokrajinskoekološke enote kot celote (Diagram 6). 


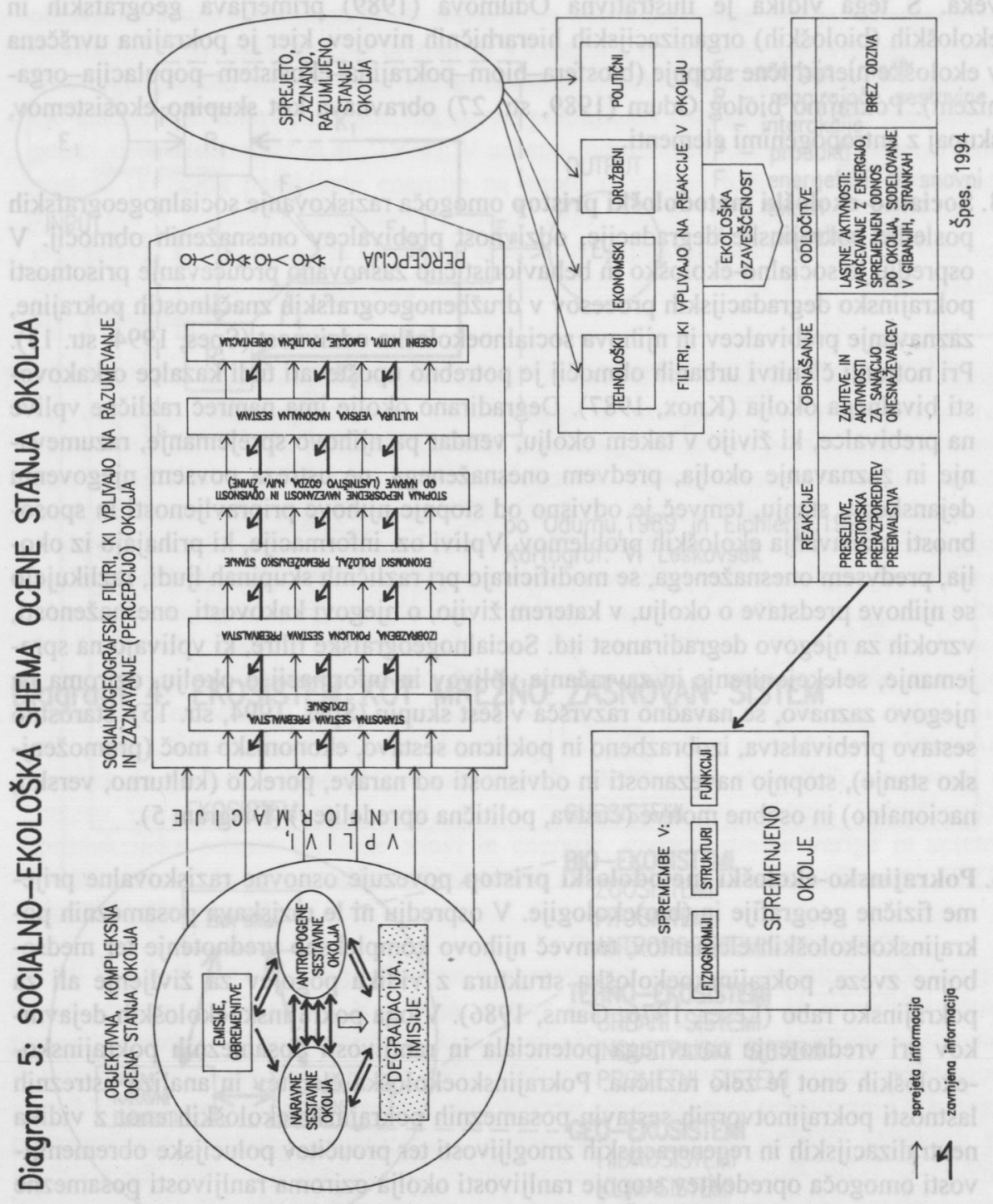




\section{Diagram 6: METODOLOGIJA IZDELAVE ŠTUDIJE RANLJIVOSTI OKOLJA Z VIDIKA NJEGOVE OBREMENLJIVOSTI}

1. nivo

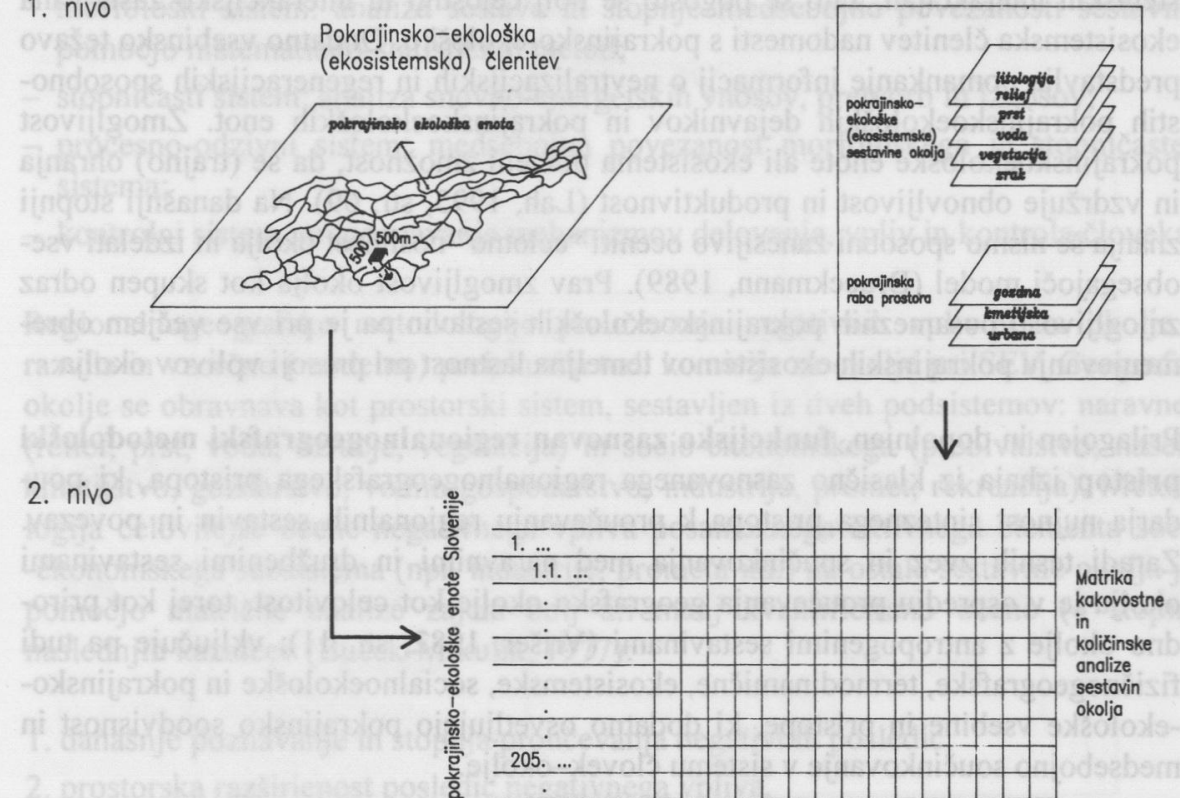

Inventarizacija prostoro

3. nivo

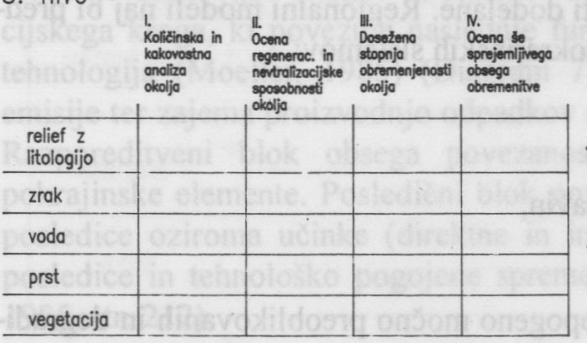

Matrika ocene ranljivosti pokrajinsko-ekološke enote

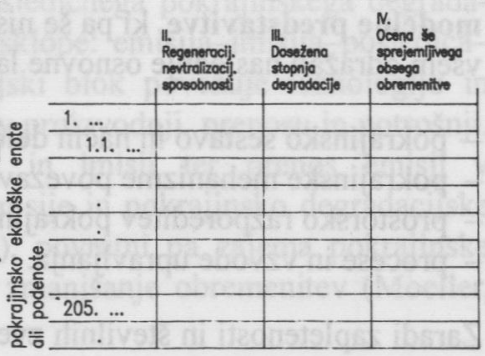

Matrika predlogov stopnje varovonja pokrajinsko-ekoloskih enot 
Študije skupne ranljivosti (občutjivosti in obremenljivosti) so vsebinsko-metodološka osnova za izdelavo celovitih presoj okolja in izoblikovanje predlogov za njegovo varovanja (Marušič, 1994). Pokrajinskoekološki pristop ocene ranljivosti je $v$ fazi snovanja, osnovni problem pa predstavlja pomankanje informacij o ekosistemskih interakcijah, zato se pogosto še bolj celostno in interakcijsko zasnovana ekosistemska členitev nadomesti s pokrajinsko-ekološko. Dodatno vsebinsko težavo predstavlja pomankanje informacij o nevtralizacijskih in regeneracijskih sposobnostih pokrajinskoekoloških dejavnikov in pokrajinskoekoloških enot. Zmogljivost pokrajinskoekološke enote ali ekosistema pomeni zmožnost, da se (trajno) ohranja in vzdržuje obnovljivost in produktivnost (Lah, 1995, str. 69). Na današnji stopnji znanja še nismo sposobni zanesljivo oceniti "celotno" nosilnost okolja in izdelati vseobsegajoči model (Brueckmann, 1989). Prav zmogljivost okolja kot skupen odraz zmogljivosti posameznih pokrajinskoekoloških sestavin pa je pri vse večjem obremenjevanju pokrajinskih ekosistemov temeljna lastnost pri presoji vplivov okolja.

5. Prilagojen in dopolnjen, funkcijsko zasnovan regionalnogeografski metodološki pristop izhaja iz klasično zasnovanega regionalnogeografskega pristopa, ki poudarja nujnost sinteznega pristopa $\mathrm{k}$ proučevanju regionalnih sestavin in povezav. Zaradi tesnih zvez in součinkovanja med naravnimi in družbenimi sestavinami okolja je $v$ ospredju proučevanja geografsko okolje kot celovitost, torej kot prirodno okolje $\mathrm{z}$ antropogenimi sestavinami (Vrišer, 1982, str. 11); vključuje pa tudi fizičnogeografske, termodinamične, ekosistemske, socialnoekološke in pokrajinsko-ekološke vsebine in pristope, ki dodatno osvetljujejo pokrajinsko soodvisnost in medsebojno součinkovanje $\mathrm{v}$ sistemu človek-okolje.

\section{III}

Razen matričnih in statistično-matematičnih prikazov ter analiz se zaradi kompleksnosti regionalnega sistema "človek-okolje" uporabljajo poenostavljene regionalne modelne predstavitve, ki pa še niso v celoti dodelane. Regionalni modeli naj bi predvsem odražali naslednje osnovne lastnosti pokrajinskih sistemov:

- pokrajinsko sestavo in način delovanja,

- pokrajinske mehanizme povezav,

- prostorsko razporeditev pokrajinskih sestavin,

- procese in vzvode upravljanja.

Zaradi zapletenosti in številnih zvez $\mathrm{v}$ antropogeno močno preoblikovanih in degradiranih pokrajinskih sistemih je smiselna uporaba serije modelov: splošnih, grafičnih, kartografskih, matematičnih. Preobraženski (1984) sodi, da nudi grafična modelna predstavitev za razliko od matematičnih modelov bolj jasno predstavo realnosti in poudarja tudi njegovo primernost za interdisciplinarno raziskovanje in na drugi strani za poenostavitev empiričnega regionalnega raziskovanja. 
Regionalno zasnovano proučevanje degradacijskih pojavov in procesov lahko opravimo na osnovi modela notranje kompleksnosti pokrajinskih sistemov (Chorley-Kennedy, 1971):

- morfološki sistem: analiza sestave in stopnje medsebojne povezanosti sestavin s pomočjo matematično-statističnih metod;

- stopničasti sistem: analiza snovno-energetskih vnosov, pretvorb in iznosov;

- procesno-odzivni sistem: medsebojna povezanost morfološkega in stopničastega sistema;

- kontrolni sistem: prepoznavanje mehanizmov delovanja, vpliv in kontrola človeka.

Regionalnogeografsko metodologijo proučevanja negativnih vplivov na okolje je razvila in vzorčno (modelno) preizkusila tudi komisija za okolje pri SEV. Geografsko okolje se obravnava kot prostorski sistem, sestavljen iz dveh podsistemov: naravnega (relief, prst, voda, ozračje, vegetacija) in socio-ekonomskega (prebivalstvo, naselja, kmetijstvo, gozdarstvo, vodno gospodarstvo, industrija, promet, rekreacija). Metodologija celovitejše ocene negativnega vpliva posameznega aktivnega elementa socio-ekonomskega subsistema (npr. industrije, prometa itd.) na ostale sestavine okolja je s pomočjo matrične analize zajela bolj ali manj kvantificirano oceno (4 stopnje) naslednjih kazalcev (Buček-Mikulik, 1977):

1. današnje poznavanje in stopnja proučevanja negativnih posledic,

2. prostorska razširjenost posledic negativnega vpliva,

3. intenzivnost posledic negativnega vpliva,

4. pomen posledic negativnega vpliva $\mathrm{z}$ vidika celotne regije.

Antropogene pokrajinske procese in učinke lahko raziskujemo tudi $\mathrm{s}$ pomočjo modelno zasnovane analize in sinteze vzročno-posledičnega pokrajinskega degradacijskega kroga, ki povezuje naslednje funkcijske sklope: emisija-imisija-posledicatehnologija (Moeller, 1985) (Diagram 7). Emisijski blok povezuje tehnologijo in emisije ter zajema proizvodnjo odpadkov (emisij) v proizvodnji, prenosu in potrošnji. Razporeditveni blok obsega povezanost emisij in imisij ter prenos emisij v pokrajinske elemente. Posledični blok povezuje imisije in pokrajinsko degradacijske posledice oziroma učinke (direktne in indirektne), povratni pa zajema pokrajinske posledice in tehnološko pogojene spremembe za zmanjšanje obremenitev (Moeller, 1985, str. 212).

Regionalnogeografskim modelom proučevanja pokrajinske degradacije je metodološko in vsebinsko blizu model analize vplivov človekovih dejavnosti na okolje, ki se je razvil v okviru nastajajoče interdisciplinarne znanosti o okolju (Chiras, 1988, str. 96) (Diagram 8). 


\title{
Diagram 7: MODEL VZROČNO-POSLEDICNEGA DEGRADACIJSKEGA RAZISKOVANJA
}

\author{
RAZPOREDITVENI BLOK
}

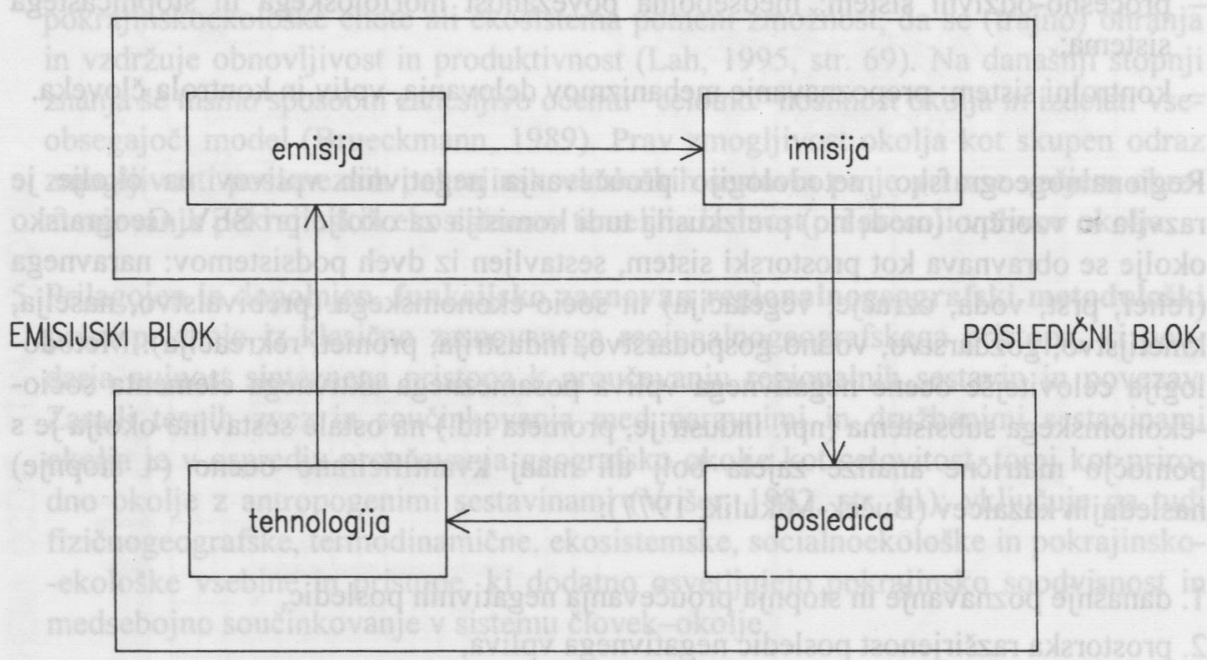

POVRATNI BLOK

Möller, 1985

Kartograf: V. Leskovšek 


\section{Diogram 8: MODEL ANALIZE VPLIVA ČLOVEKOVIH DEJAVNOSTI NA OKOLJE}

a) VRSTE UČINKOV

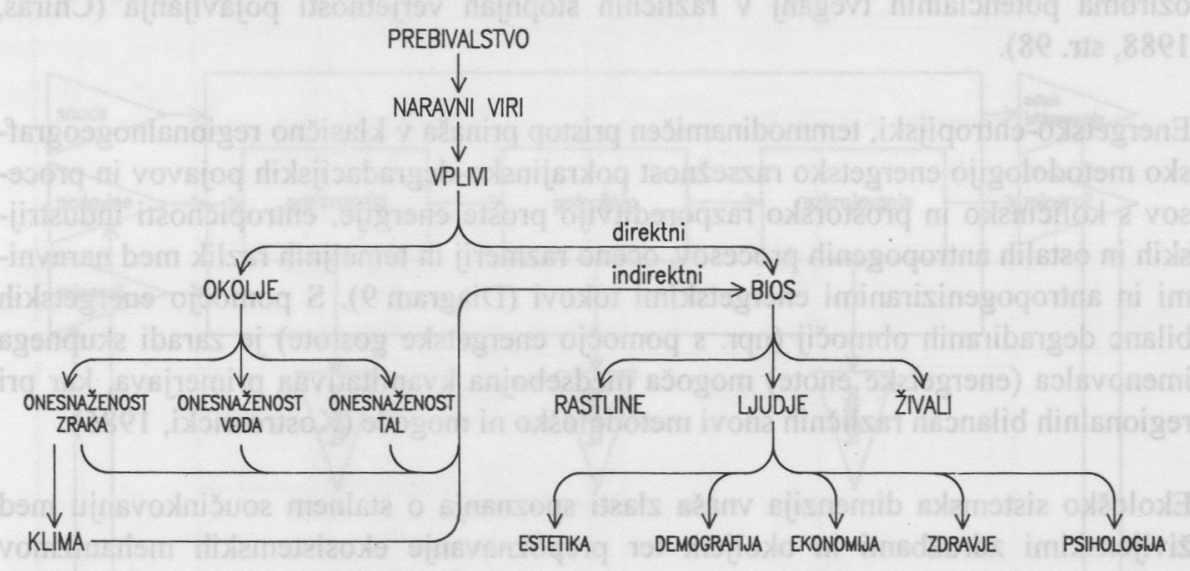

b) MATRIČNI PRIKAZ UČINKOV

\begin{tabular}{|c|c|c|c|c|}
\hline VPLIMI & $\begin{array}{l}\text { VISOKA } \\
\text { VERJETNOST }\end{array}$ & $\begin{array}{l}\text { SREDNJA } \\
\text { VERJETNOST }\end{array}$ & $\begin{array}{l}\text { NIZKA } \\
\text { VERJETNOST }\end{array}$ & $\begin{array}{l}\text { NEZNANA } \\
\text { VERJETNOST }\end{array}$ \\
\hline \multirow{2}{*}{$\begin{array}{l}\text { ONESNAŽEENOST } \\
\text { ZRAKA }\end{array}$} & alomodi on it & 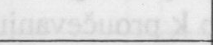 & 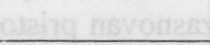 & onteolea nods \\
\hline & W5070 ant ano & $640002=01$ & 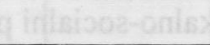 & 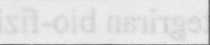 \\
\hline \multirow{2}{*}{$\begin{array}{l}\text { ONESNAŽENOST } \\
\text { VODA }\end{array}$} & 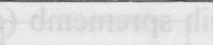 & 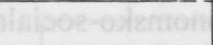 & 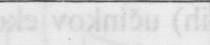 & 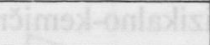 \\
\hline & 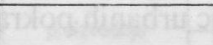 & 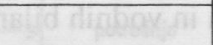 & 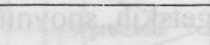 & $9+2 x+409$ \\
\hline \multirow{2}{*}{$\underset{\text { TAL }}{\text { ONESNAŽENOST }}+$} & & & & \\
\hline & & & & \\
\hline \multirow{2}{*}{$\begin{array}{ll}\text { RASTLINE } & + \\
& -\end{array}$} & & & 60 & \\
\hline & 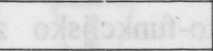 & 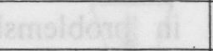 & noing imisleo & abojera intins \\
\hline \multirow{2}{*}{ LJUDJE } & 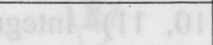 & 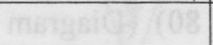 & 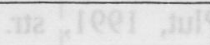 & 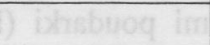 \\
\hline & 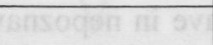 & 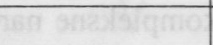 & 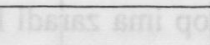 & $2 \pi 9+4+2000-0$ \\
\hline \multirow{2}{*}{ ŽIVAL } & 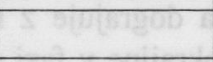 & 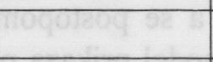 & 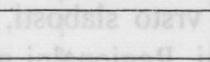 & 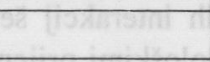 \\
\hline & & & & \\
\hline
\end{tabular}

Chiras, 1988

Kartograf: Veronika Leskovšek 
Izhaja iz vse večjega vpliva človeške populacije na naravne vire in preko njihove uporabe na neživi in živi svet. Model obravnava neposredne in posredne povratne vplive dejavnosti človeka in vključuje razen pokrajinskih tudi ekonomske, demografske, zdravstvene, psihološke in estetske posledice na sestavine okolja. S pomočjo matrike lahko sintezno prikažemo pozitivne in negativne učinke določenih tehnologij oziroma potencialnih tveganj $\mathrm{v}$ različnih stopnjah verjetnosti pojavljanja (Chiras, 1988, str. 98).

Energetsko-entropijski, temmodinamičen pristop prinaša $v$ klasično regionalnogeografsko metodologijo energetsko razsežnost pokrajinsko-degradacijskih pojavov in procesov s količinsko in prostorsko razporeditvijo proste energije, entropičnosti industrijskih in ostalih antropogenih procesov, oceno razmerij in temeljnih razlik med naravni$\mathrm{mi}$ in antropogeniziranimi energetskimi tokovi (Diagram 9). S pomočjo energetskih bilanc degradiranih območij (npr. s pomočjo energetske gostote) je zaradi skupnega imenovalca (energetske enote) mogoča medsebojna kvantitativna primerjava, kar pri regionalnih bilancah različnih snovi metodološko ni mogoče (Kostrowicki, 1986).

Ekološko sistemska dimenzija vnaša zlasti spoznanja o stalnem součinkovanju med življenskimi združbami in okoljem ter prepoznavanje ekosistemskih mehanizmov ravnovesja (zlasti negativnih, izravnalnih povratnih lokov) $\mathrm{v}$ naravnih in naravi bližnjih biotopih, ki predstavljajo $\mathrm{v}$ nasprotju $\mathrm{z}$ urbanimi ekosistemi življenje podpirajoče ekosisteme (Odum, 1989, str. 8). Pokrajinskoekološka razsežnost vnaša vsebino in metodologijo proučevanja pokrajinske ranljivosti kot nove kvalitete celote, kot rezultante pokrajinskoekološke zmogljivosti (samočistilnih in regeneracijskih sposobnosti) in emisijskih obremenitev pokrajinskega sistema. Zlasti v mestnih pokrajinah je potreben celostno zasnovan pristop k proučevanju, ki ga Douglas (1983) označuje kot integriran bio-fizikalno-socialni pristop, s poudarkom na proučevanju pokrajinskih (bio-fizikalno-kemičnih) učinkov ekonomsko-socialnih sprememb (emisije, rabe prostora) s pomočjo energetskih, snovnih in vodnih bilanc urbanih pokrajin.

Kljub dodatnim vsebinsko-metodološkim dimenzijam gre pri sistemsko zasnovanem, sinteznem proučevanju antropogene pokrajinske preobrazbe še vedno za tradicionalno regionalnogeografsko vsebinsko in metodološko zasnovo, z nekaterimi dodatnimi, specifičnimi metodološkimi prijemi in problemsko-funkcijsko zasnovanimi vsebinskimi poudarki (Plut, 1991, str. 80) (Diagram 10, 11). Integriran (regionalen) geo-eko-socialni pristop ima zaradi kompleksne narave in nepoznavanja vseh pokra-jinskih interakcij še vrsto slabosti, a se postopoma dograjuje z novimi teoretskometodološkimi prijemi. Regionalni model prikaza pokrajine $v$ fazi degradacije označuje obravnava naravnih in antropogeniziranih snovno-energetskih vnosov, načinov in pokrajinskih posledic snovno-energetskih preobrazb in prikazov snovno-energetskih iznosov ter razmerij do sosednjih pokrajinskih sistemov. Poudarek je na pokrajinskih procesih preoblikovanja, ki zaradi prevlade pozitivnih povratnih pokrajinskih lokov 


\section{Diagram 9: SNOVNO-ENERGETSKI TOKOVI V BIOSFERI IN TEHNOSFERI}

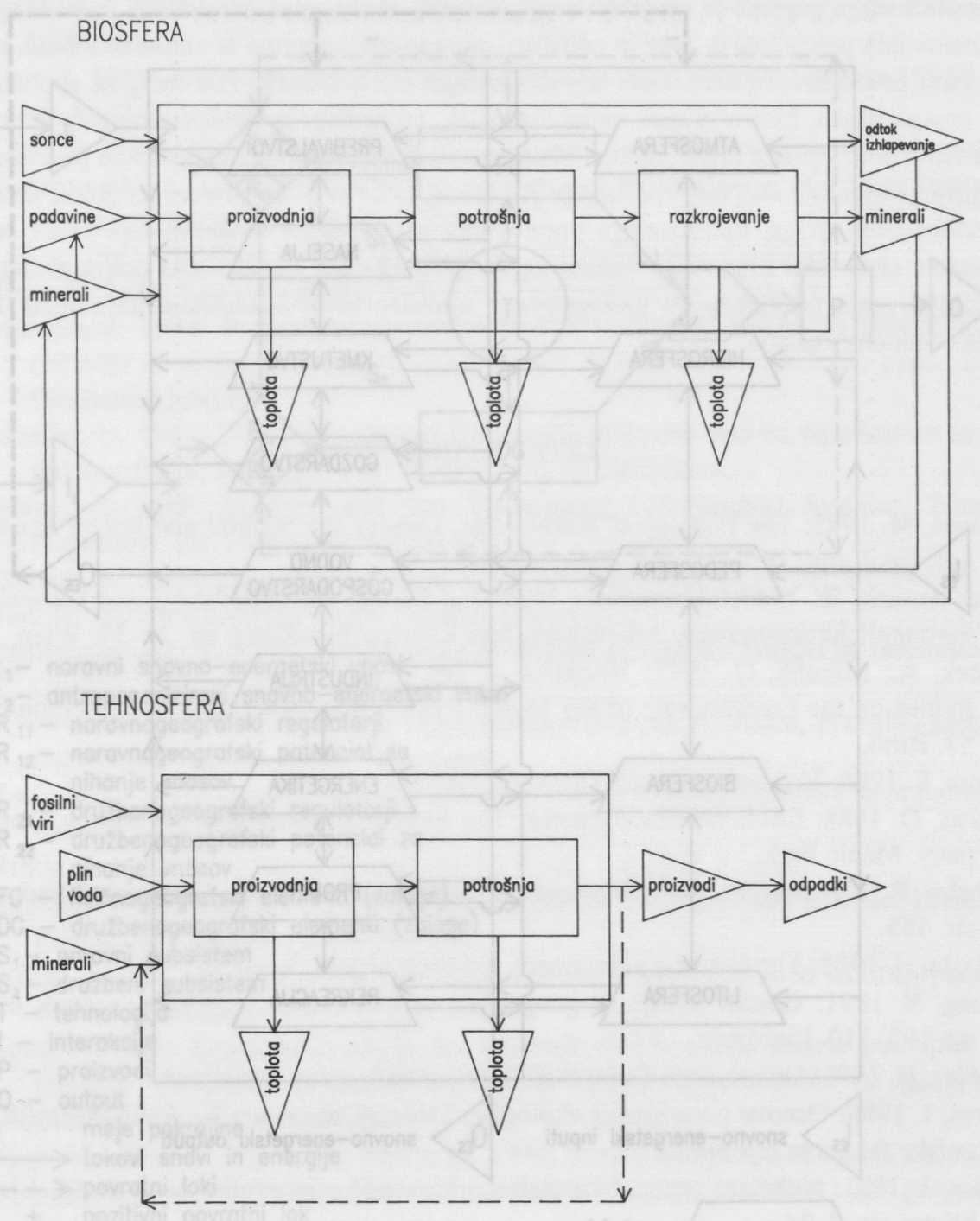

Plut,1995

Kartograf: V. Leskovšek 


\section{Diagram 10: POKRAJINA KOT SNOVNO-ENERGETSKI SISTEM}

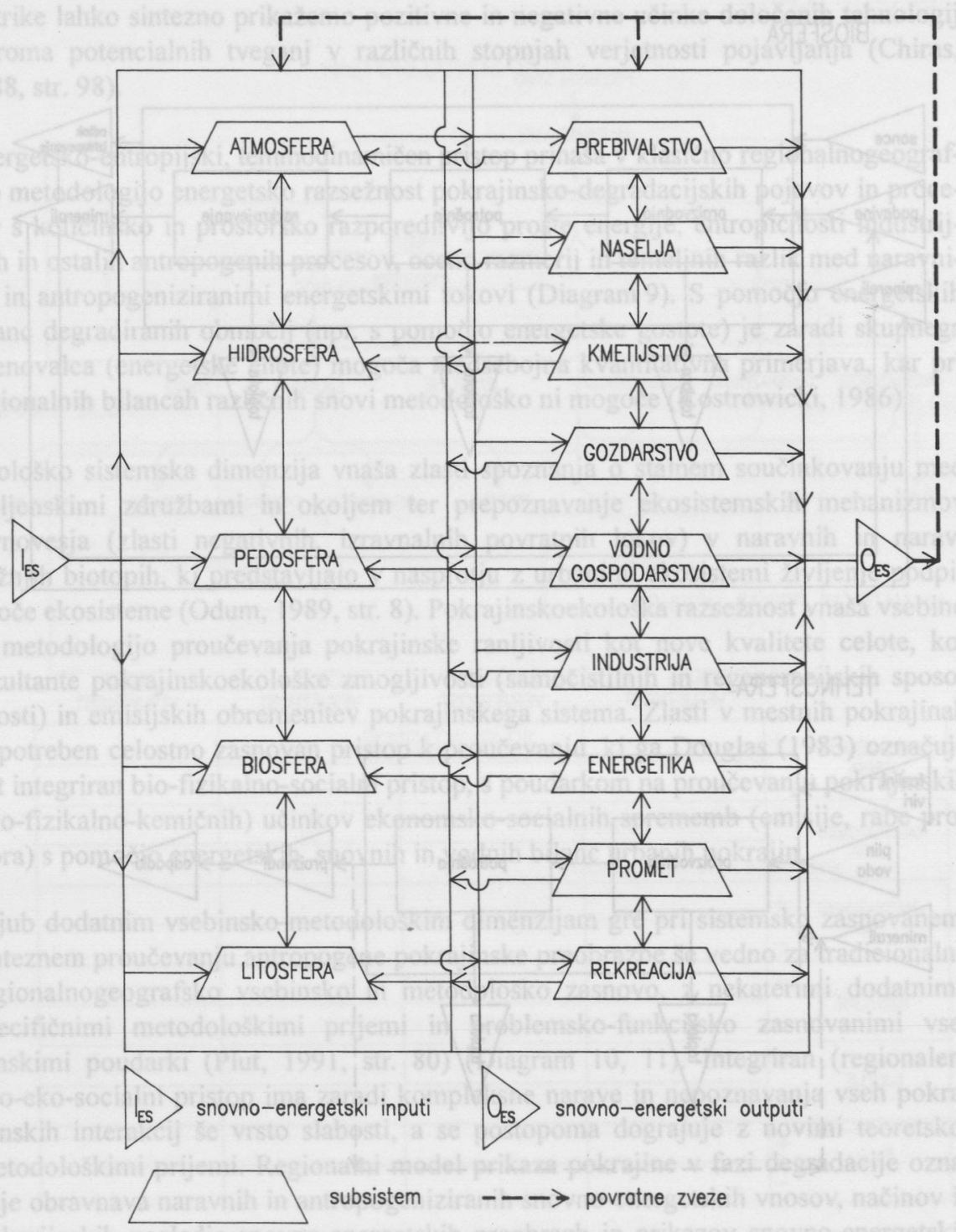

Plut,1995

Kartograf: V. Leskovšek 


\section{Diagram 11: MODELNA PREDSTAVITEV POKRAJINE \\ KOT DEGRADACIJSKEGA PROSTORSKEGA SISTEMA}

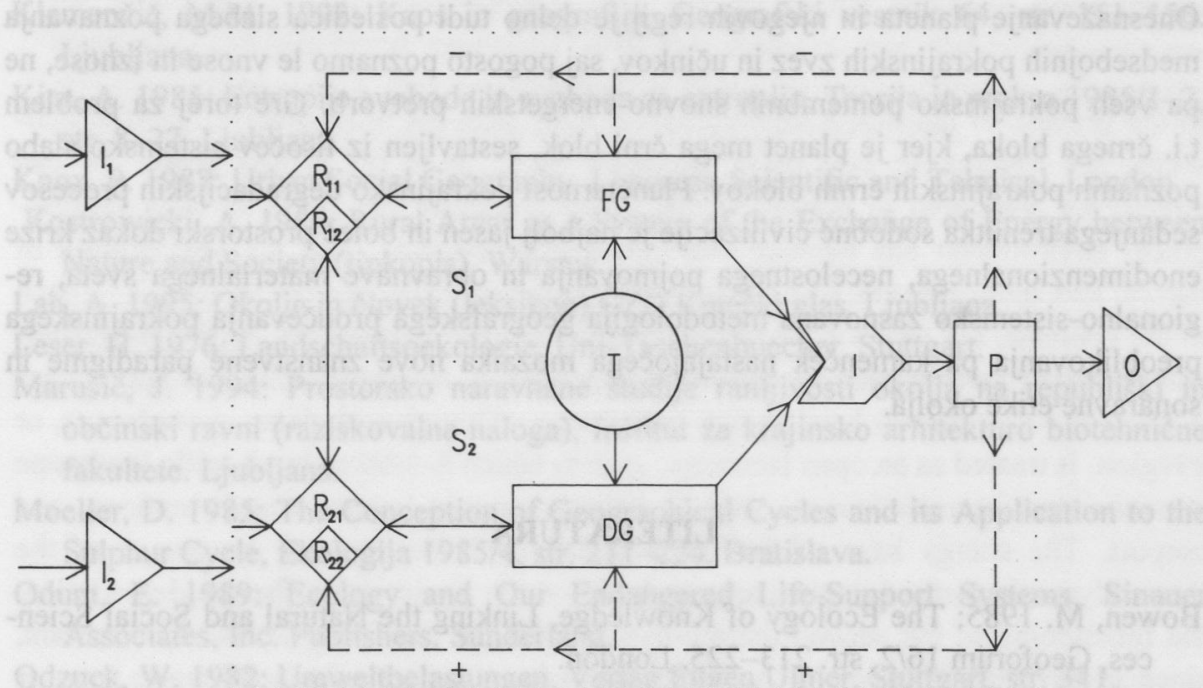

$I_{1}-$ naravni snovno-energetski vnosi

$\mathrm{I}_{2}$ - antropogenizirani snovno-energetski vnosi

$\mathrm{R}_{11}$ - narovnogeografski regulatorji

$R_{12}$ - narovnogeografski potencial za nihanje vnosov

$R_{21}$ - družbenogeografski regulatorji

$\mathrm{R}_{22}$ - družbenogeografski potencial za nihanje vnosov

FG - fizǐ̌nogeografski elementi (zaloge)

DG - družbenogeografski elementi (zaloge)

$\mathrm{S}_{1}$ - naravni subsistem

$\mathrm{S}_{2}$ - družbeni subsistem

$T$ - tehnologija

I - interakcije

P - proizvodi

O - output meje pokrajine

$\longrightarrow$ tokovi snovi in energije

$-\rightarrow$ povratni loki

+ pozitivni povratni lok

- negativni povratni lok 
vodijo $\mathrm{k}$ vse večji pokrajinski entropiji in $\mathrm{s}$ tem $\mathrm{k}$ povečani degradaciji pokrajine, katere intenzivnost je razen od obremenitev odvisna tudi od zmogljivosti samoregeneracijskih mehanizmov pokrajine.

Onesnaževanje planeta in njegovih regij je delno tudi posledica slabega poznavanja medsebojnih pokrajinskih zvez in učinkov, saj pogosto poznamo le vnose in iznose, ne pa vseh pokrajinsko pomembnih snovno-energetskih pretvorb. Gre torej za problem t.i. črnega bloka, kjer je planet mega črni blok, sestavljen iz tisočev sistemsko slabo poznanih pokrajinskih črnih blokov. Planetarnost pokrajinsko degradacijskih procesov sedanjega trenutka sodobne civilizacije je najbolj jasen in boleč prostorski dokaz krize enodimenzionalnega, necelostnega pojmovanja in obravnave materialnega sveta, regionalno-sistemsko zasnovana metodologija geografskega proučevanja pokrajinskega preoblikovanja pa kamenček nastajajočega mozaika nove znanstvene paradigme in sonaravne etike okolja.

\section{LITERATURA}

Bowen, M. 1985: The Ecology of Knowledge, Linking the Natural and Social Sciences, Geoforum 16/2, str. 213-225. London.

Bueckemann, W. 1989: Methodische Probleme bei der Durchfuehrung von Umweltvertraeglichkeitpurefung, Arbeitskreis fuer Regionalforschung, str. 24-39. Wien.

Buček, A.; Mikulik, O. 1977: Valuation of the Negative Effects of Economic Activities on the Environment of the Model Region of Liberec, Studia Geographica 57. Brno.

Capra, F. 1986: Vrijeme preokreta (prevod), Naprijed. Zagreb.

Chiras, D. 1988: Environmental Science, The Benjamin/Cummings Publishing Company. Menlo Park.

Chorley, R.; Kennedy, B. 1971: Physical Geography - A Systems Approach, London, str. 369.

Douglas, I. 1983: The Urban Environment, Edward Arnold. London.

Drozg. V. 1991: Gestalt teorija in geografsko proučevanje, Geografski vestnik 63, str. 103-110. Ljubljana.

Eichler, H. 1993: Oekosystem Erde, B. I. Taschenbuchverlag. Manheim.

Gams, I. 1986: Osnove pokrajinske ekologije, Oddelek za geografijo ljubljanske filozofske fakultete. Ljubljana.

Gams, I. 1991: Nekatere geografske stalnice Slovenije, Geografski vestnik 63, Ljubljana, str. 7-24.

Georgescu-Roegen, N. 1986: Bioekonomski vidiki entropije, Teorija in praksa 1986/9-10, str. 977-993. Ljubljana.

Gilbert, O. 1991: The Ecology of Urban Habitats, Chapman and Hall. London. 
Haggett, P. 1972: Geography: A Modern Synthesis, Harper and Row Series in Geography. New York.

Haigh, M. 1985: Geography and General System Theory, Geoforum 16/2, str. 191-202. London.

Klemenčič, M.M. 1992: Kaos in geografija, Geografski vestnik 64, str. 151-156. Ljubljana.

Kirn, A. 1985: Entropija svobode in svoboda za entropijo, Teorija in praksa 1985/1-2, str. 8-27. Ljubljana.

Knox, P. 1987: Urban Social Geography, Longman Scientific and Tehnical. London.

Kostrowicki, A. 1986: Rural Areas as a System of the Exchange of Energy between Nature and Society (tipkopis). Warsaw.

Lah, A. 1995: Okolje in človek (leksikon) ČZD Kmečki glas. Ljübljana.

Leser, H. 1976: Landschaftsoekologie, Uni-Taschenbuecher. Stuttgart.

Marušič, J. 1994: Prostorsko naravnane študije ranljivosti okolja na republiški in občinski ravni (raziskovalna naloga), Inštitut za krajinsko arhitekturo biotehnične fakultete. Ljubljana.

Moeller, D. 1985: The Conception of Geographical Cycles and its Application to the Sulphur Cycle, Ekologija 1985/4, str. 211-224. Bratislava.

Odum, E. 1989: Ecology and Our Endangered Life-Support Systems, Sinauer Associates, Inc. Publishers. Sunderland.

Odzuck, W. 1982: Umweltbelastungen, Verlag Eugen Ulmer, Stuttgart, str. 341.

Plut, D. 1991: Entropijska zanka, Didakta. Radovljica.

Preobrazhensky, V. 1984: Trends in the Evolution of Graphic Model of Geosystems, Geoforum 19/ 1, str. 83-88. London.

Przewozniak, M. 1989: Konflikty miasto-srodowisko przyrodnicze, Przeglad geograficzny LXI/1-2, str. 51-62. Warszawa.

Radinja, D. 1972: Onesnaženost človekovega okolja v luči geografske terminologije, Geografski obzornik 1972/4, Ljubljana, str. 35-39.

Rifkin, J. 1986: Posustajanje budućnosti (prevod), Naprijed. Zagreb.

Strahler, A.N.; Strahler, A.H. 1974: Introduction to Environmental Science, Hamilton Publishing Company. Santa Barbara.

Strnad, J. 1987: Ali sodi entropijski zakon v srednjo šolo, Vzgoja in izobraževanje 5, str. 14-22. Ljubljana.

Špes, M. 1994: Degradacija okolja kot dejavnik diferenciacije urbane pokrajine (na izbranih slovenskih primerih) (doktorska disertacija), Oddelek za geografijo filozofske fakultete. Ljubljana.

Špes, M.; Plut, D.; Natek, D.; Natek, M. 1994: Študija ranljivosti okolja in osnove za pripravo podzakonskega akta (raziskovalna naloga), Inšitut za geografijo Univerze. Ljubljana.

Tarman, K. 1992: Osnove ekologije in ekologija živali, DZS. Ljubljana.

Vrišer, I. 1982: Uvod v geografijo, Oddelek za geografijo filozofske fakultete. Ljubljana. 